\title{
INFLUENCE OF INTELLECTUAL CAPITAL, INCOME DIVERSIFICATION ON FIRM VALUE OF COMPANIES WITH PROFITABILITY MEDIATION: INDONESIAN BANKING
}

\author{
Windie Yustyarani, Indah Yuliana \\ Islamic State University Maulana Malik Ibrahim Malang \\ e-mail:wyustyarani@gmail.com
}

\begin{abstract}
This study aims to examine and analyze the effect of intellectual capital and income diversification on firm value mediated by profitability. This study uses secondary data from annual reports on banks listed on the Indonesia Stock Exchange in 2013-2018. There are 30 banking samples in this study based on established criteria (purposive sampling). Data analysis using the WarpPLS 6.0 program. The results showed that intellectual capital had a positive effect on profitability and on firm value, income diversification had a negative effect on profitability, while it was found to have no effect on firm value, profitability had a positive effect on firm value, intellectual capital had an indirect effect on firm value mediated by profitabilit with partial mediation, while mediation is not supported by the indirect effect of Income Diversification on Firm Value.
\end{abstract}

Keywords: Intellectual Capital, Income Diversification, Profitability, Firm Value

\begin{abstract}
Abstrak
Penelitian ini bertujuan untuk menguji dan menganalisis pengaruh modal intelektual dan diversifikasi pendapatan terhadap nilai perusahaan dengan dimediasi oleh profitabilitas. Penelitian ini menggunakan data sekunder laporan tahunan pada perbankan yang terdaftar di BEI tahun 2013-2018. Terdapat 30 perbankan menjadi sampel dalam penelitian ini berdasarkan kriteria yang ditetapkan (purposive sampling). Analisis data menggunakan program WarpPLS 6.0. Hasil penelitian menunjukkan bahwa Modal intelektual berpengaruh positif terhadap Profitabilitas maupun terhadap Nilai Perusahaan, Diversifikasi Pendapatan berpengaruh negatif terhadap Profitabilitas, sedangkan ditemukan tidak berpengaruh terhadap Nilai Perusahaan, Profitabilitas berpengaruh positif terhadap Nilai Perusahaan, Modal Intelektual berpengaruh secara
\end{abstract}


tidak langsung terhadap Nilai Perusahaan dimediasi oleh Profitabilitas secara parsial (partial mediation), sedangkan mediasi tidak didukung pada pengaruh tidak langsung Diversifikasi Pendapatan terhadap Nilai Perusahaan.

Kata kunci: Modal Intelektual, Diversifikasi Pendapatan, Profitabilitas, Nilai Perusahaan

\section{INTRODUCTION}

Banking has a considerable contribution to the country's income with its function as a Financial Intermediary institution, i.e. intermediaries between the users of funds and fund owners (Arief and Yahya, 2014). Based on the Indonesian economic report of 2018, about 70 per cent of economic financing was sourced from banking credit. Banking as a company certainly has the purpose of the operation that has been done. Theory of the firm implies that optimizing the wealth or firm value and the welfare of shareholders is the primary purpose of the company (Salvatore, 2005).

Firm value is the interpretation of the welfare of shareholders based on the company's share price. The higher amount of the share price of the book's value indicates that the higher protection of the holder, and vice versa, the lower amount of the share price of the book value shows the lower welfare of shareholders according to Handoko (Arief and Yahya, 2014). The price of banking stocks in Indonesia, one of which is reflected by the index of INFOBANK15. This index measures the performance of the stock price of 15 banking with high liquidity and good fundamental factors. The share price index of INFOBANK15 in 2017-2019 was increased. Still, in January and February, the year 2020 of the banking share price decreased about 27 rupiahs in January and around 44 rupiahs in February 2020 for the closing price of each stock sheet, where other price indexes also tended to decline.

Several factors can affect the effort to increase the firm value, namely: (a) good governance, (b) the ability to generate profit, (c) Investors generally avoid risk (Sudana, 2009). The strength of the company to make a profit can be seen from the profitability ratio. In improving profitability, the company's resources are optimized to generate profit, both through operational and investment activities with the creation of valueadded.

The business process has undergone development, along with the development of technology and science. The business process that was based on energy (labour-based business) has also evolved into the market based on knowledge-based business so that the company based on knowledge to be the main characteristics of the company (Sawarjuwono and Kadir, 2003). According to Petty and Guthrie (Subkhan and Citraningrum, 2010), intellectual capital is one of the approaches in measuring and valuation of intangible assets. Intellectual capital is considered to be instrumental in improving the firm value and financial performance. The high amount of intellectual capital (VAIC ${ }^{\mathrm{TM}}$ ) shows the efficient use of the company's equity, thereby creating value-added for the company (Sunarsih, Made, and Mendra, 2012). The efficient use of intellectual capital will increase the company's market value (Hadiwijaya and Rohman, 2013). The hidden value derived from the difference between the share price and the value of the book is believed to be the intellectual capital that is appreciated and recognized by the market. 
Then in increasing profitability can be done with a diversified strategy that can be done on the company's assets and revenues. Diversification is a corporate strategy to increase profitability by increasing sales volume through new product or market form (Sari, Wiratno, and Suyono, 2014). Income diversification is a bank strategy in obtaining revenues that are not only from a single source but some sources. Interest income is the main revenue of banking from the traditional activity of credit distribution, while in the diversification of banking income is looking for other new revenue sources that are expected to be more stable, i.e. non-interest income (noninterest income) (Widiasari and Pangestuti, 2015). In the last seven years (2013-2017) based on the banking statistics report, the banking revenue is still dominated by bank interest income, with an average of 73 per cent of total bank revenues.

Empirically, intellectual capital (IC) has a positive effect on Return on Assets (ROA) (Alipour, 2012; Octavio and Soesetio, 2019; Tran and Hong Vo, 2018) and against Return on Equity (ROE) (Buallay, 2019; Wijayani, 2017). Research on conventional banks and Sharia banks is also carried out with the result of the impact IC on ROE only on sharia banks, while IC has an influence on ROA and ROE on conventional banks (Buallay, 2019). Meanwhile, the results differ in the research conducted (Aida and Rahmawati, 2015) that intellectual capital does not affect the ROE. Then the research related to intellectual capital and firm value was also done earlier by some researchers. (Arief and Yahya, 2014; Putra, 2012; Sudibya and Restuti, 2014) found that intellectual capital has a positive influence on Price to Book Value (PBV). While the research results (Aida and Rahmawati, 2015; Hadiwijaya and Rohman, 2013; Werastuti, 2014) intellectual capital has no significant effect on the firm value. (Lestari, 2017) finds the intellectual capital negatively affects PBV. Based on the research results (Arief and Yahya, 2014; Hadiwijaya and Rohman, 2013) The intellectual capital is indirectly affected by the firm value, namely with the ratio of profitability that is proscribed on Return on Assets (ROA) or Return on Equity (ROE) which is the second relationship (Sudibya and Restuti, 2014). However, its influence is not more reliable than its immediate impact.

Research (Sianipar, 2015) found that income diversification has a positive effect on Return on Assets (ROA). Not only on the return of assets, but the influence of income diversification on two profitability proxies namely ROA and ROE was also found to have positive results (Luu et al., 2019; Setiawan and Pramika, 2019; Sharma and Anand, 2018). Different with research by (Hafidiyah and Trinugroho, 2016), the results show that income diversification has a negative effect on ROA and ROE (Turkmen and Yigit, 2012).

The income diversification has a positive influence on the firm value being proscribed with the amount of Tobin's Q (Lukmawijaya and Suk, 2015) instead the study was not supported by research results (Aprilia and Darmawan, 2019; Natalia, Kurniawan, and Firsty, 2016; Sianipar, 2015) which results show that the income diversification has no significant effect on the firm value. (Aprilia and Darmawan, 2019; Hasibuan, Ar, and Endang, 2016; Simetris and Darmawan, 2019) found that Return on Equity (ROE) positively affects the firm value. However, different with the research results (Cahya and Riwoe, 2018) The ROE has a negative effect on the firm value, but Return on Assets (ROA) positively affects the firm value. (Murni and Sabijono, 2018) found that ROE did not significantly influence the firm value.

Some previous research results showed the inconsistency of the results, so more research needs to be done. This research will analyze intellectual capital and income 
diversification on firm values with profitability as an intervening variable. The purpose of this research is to analyze and acknowledge: (1) The effect of intellectual capital and income diversification to profitability, (2) Effect of intellectual capital and income diversification to firm value, (3) Profitability effect on firm value, (4) The effect of intellectual capital of the firm value with mediated by profitability, (5) The effect of income diversification on firm values with mediated by profitability. The results of the research can be used as a consideration in investment decisions for investors, as well as to know the magnitude of the firm value is influenced by intellectual capital and income diversification to determine the competing strategy for the company.

\section{LITERATURE REVIEW}

\section{Stakeholder Theory}

This theory positions the power of authority that stakeholders have to influence management in the process of utilization of potential companies have. Utilization of potential with good and maximal can create value-added to encourage financial performance further. Value Added Intellectual Coefficient $\left(\mathrm{VAIC}^{\mathrm{TM}}\right.$ ) In this case is used to measure the added value (Ulum, 2007:5-6). The purpose of this theory is to help managers to manage the company more effectively, understand the environmental stakeholders and the relationships that exist in the company's environment. More broadly, the purpose of this theory is to help managers in activities undertaken to increase the value and minimize losses for stakeholders (Ulum, 2009:5). In this case, the relationship built between the company and stakeholders plays an essential role in the process of increasing the firm value.

\section{Signalling Theory}

Gesture or signal is the company's action to give an overview for outside the company especially investors in the form of information related to activities that have been done by the management in realizing the owner's wishes (Brigham and Houston, 2001: 36). Information published will signal to make investment decisions for investors (Hartono, 2012). One of the information that can be a signal for outside parties and investors is an annual report issued by the company.

\section{Intellectual capital}

Intellectual Capital's interest Is in the presence of an article titled "Brain PowerHow Intellectual Capital Is Becoming America's Most Valuable Asset" written by Thomas A. Stewart in June 1991 so that it began to emerge research that contributed to the identification, measurement and reporting of Intellectual Capital. Definition of intellectual capital according to (Stewart, 1997) namely:

"The sum of everything everybody in your company knows that gives you a competitive edge in the market place. It is intellectual material - knowledge, information, intellectual property, experience - that can be put to use to create wealth ".

The intellectual capital is measured by Value Added Intellectual Coefficient (VAIC ${ }^{\mathrm{TM}}$ ) is a method developed by Pulic (1997) (Ulum, 2009). The components of the intellectual capital forming are Value Added Capital Employed (VACA), Value Added Human Capital (VAHU), and Structural Capital Value Added (STVA). 


\section{Income Diversification}

Income diversification is a bank strategy in obtaining revenues that are not only from a single source but some sources. Interest income is the primary revenue of banking from the traditional activity of credit distribution, while in the diversification of banking income is looking for other new revenue sources that are expected to be more stable, i.e. non-interest income (Widiasari and Pangestuti, 2015). Income diversification is non-interest income by calculating the proportion of non-interest income to operating profit. The source of non-interest income consists of fee income and trading income (Sianipar, 2015).

\section{Profitability}

The ratio of profitability is a ratio that measures the company's ability to gain profit from its total assets, sales or capital (Sartono, 2010: 122). Meanwhile, John J. Hampton stated that the goal of the profitability ratio is for the efficiency of the company's activities and the ability of the company to gain profit (Fred J. Weston in Sugiono, 2009: 68). Several factors are affecting the growth of profit, namely (a) the size of the company; (b) the company's age; (c) Leverage; (d) Sales rate; (e) The previous change of profit period (Baridwan, 2011: 46).

\section{Corporate values}

Firm value is the interpretation of the welfare of shareholders based on the company's share price. The higher amount of the share price of the book's value indicates that the higher protection of the holder, and vice versa, the lower amount of the share price of the book value shows the lower welfare of shareholders according to Handoko in (Arief and Yahya, 2014). There are several concepts of firm value, this concept can be used to find out which stocks grow and the price through the amount of books and Markets (Hartono, 2013: 121), among them: the value of stock-book books, market value and intrinsic value.

\section{Hypothesis}

The research hypothesis predicts the relationship between intellectual capital and income diversification to the firm value mediated by profitability. Based on Signalling Theory, profitability is one of the information that can be a signal for outside parties, including investors listed on the company's annual report to be used in consideration of investment decisions. Stakeholder Theory is centred on the welfare of the stakeholders through the creation of Value Added that can increase the company's profit. Profitability is the result of investments made in the intellectual capital, which gives a significant usage signal (Amalia and Annisa, 2018). In this case, it is intended that when the intellectual capital owned by the company is well managed in, both in the operation of the company and in the form of investment, it will increase the profitability of the company also because the profitability is the result of intellectual capital use signal. The precipitation of the research supports it; namely, study (Alipour, 2012; Octavio and Soesetio, 2019; Tran and Hong Vo, 2018) found that intellectual capital has a positive effect on Return on Assets (ROA). (Buallay, 2019; Wijayani, 2017) also found that the intellectual capital (IC) has a positive impact on Return on Assets (ROA) and Return on Equity (ROE). Research on two types of banks, namely conventional banks and Sharia banks is also done with the result of the impact IC on the ROE only on sharia banks, while IC has an influence on ROA and ROE on conventional banks (Buallay, 2019). 
H1a: Intellectual capital has a positive effect on profitability

Income diversification is a bank strategy in obtaining income that are not only from a single source but some sources. Interest income is the primary revenue of banking from the traditional activity of credit distribution, while in the diversification of banking income is looking for other new revenue sources that are expected to be more stable, i.e. non-interest income (Widiasari and Pangestuti, 2015). When the bank only focuses on the interest income from the credit distribution while the credit risk is not managed correctly, it can lower the profitability (Widiasari and Pangestuti, 2015). Some previous studies also support it. Research (Sianipar, 2015) found that income diversification has a positive effect on Return on Assets (ROA). Not only on the return of assets, but the influence of income diversification against two profitability proxies namely ROA and ROE was also found to have positive results (Luu et al., 2019; Setiawan and Pramika, 2019; Sharma and Anand, 2018). Diversification benefits the state-owned and foreign banks and more prominently on the bank more experience in the market, while the adverse influence on the financial performance of other domestic and non-governmental banks (Luu et al. 2019).

H1b: Income diversification has a positive effect on profitability

Stakeholder theory mentions that stakeholders have the authority to influence management in the management of resources and the potential of the company's own for the sake of creating value (value creation) that can increase benefits as well for the stakeholders. Intellectual Capital is a knowledge and information that can be used to create value for the company (Purnomosidhi, 2006). The management of intellectual capital well by the company will improve the financial performance that can be a positive signal for investors so that investors are interested in investing in the company according of Putri in the journal (Amalia and Annisa, 2018). Improving the company's ability in the long term can be achieved by increasing mobilization of the company's inherent potential, mainly intangible and investing in intellectual resources, especially in human capital which is a significant factor in creating value in modern Business (Ulum, 2009: 84). Research (Arief and Yahya, 2014; Putra, 2012; Sudibya and Restuti, 2014) The result is that the intellectual capital has a positive influence on Price to Book Value (PBV). The intellectual capital component of Value Added Human Capital (VAHC), Value Added Employed (VACE) has a positive influence, while the Value Added Structural Capital (VASC) component has a negative effect on PBV (Arief and Yahya, 2014).

H2a: Intellectual capital has a positive effect on firm values

According to Hitt et al., in the article (Tatra and Wesnawati, 2017) diversification is a corporate strategy carried out at the corporate level to gain competitive advantage, or the ability to create firm value above the average competitor, through the selection and management of some different business units or businesses competing in some industries, or the product market that the research conducted by (Lukmawijaya and Suk, 2015) the result that the income diversification has a positive influence on the value of the company being proscribed with the amount of Tobin's Q 
Gain competitive advantage so that it will increase the value of the company compared with competitor companies.

H2b: Income Diversification has a positivel effect on Firm value

Signalling theory is closely related to the provision of information for outside parties, including investors as signals that can be used in consideration in investment decisions. Profitability and the firm value are also the Inforrice of the company's annual report and financial statement. The profitability of Return on Equity (ROE) is considered a representation of the wealth owned by the shareholder or firm value (Mardiyanto, 2008: 63). Several factors can affect the effort to increase the firm value, namely: (a) good governance, (b) the ability to generate profit, (c) Investors generally avoid risk (Sudana, 2009). Research (Aprilia and Darmawan, 2019; Hasibuan et al., 2016; Simetris and Darmawan, 2019) found that Return on Equity (ROE) positively affects the firm value. However, different with the research results (Cahya and Riwoe, 2018) The ROE has a negative effect on the firm value, but Return on Assets (ROA) positively affects the firm value.

H3: Profitability has a positive effect on firm values

When the intellectual capital is managed by the company well to generate Value Added and competitive advantage so that it can increase the profitability of the company, the better profitability level reflects the prospects of the company also well. Hence, it becomes a positive signal for investors to be then able to increase the value of the company. Based on the research results (Arief and Yahya, 2014; Hadiwijaya and Rohman, 2013) The intellectual capital is indirectly affected by the firm value, namely through the ratio of profitability which is proscribed by Return on Assets (ROA) or Return on Equity (ROE) (Sudibya and Restuti, 2014). However, its influence is not more reliable than its immediate impact.

H4: Profitability mediates the relationship between Intellectual Capital and Firm Value

Income diversification is done with the goal of the company not only focus on traditional income derived from credit distribution but looking for other income that comes from non-interest income so it will be expected to increase the company's revenue source and look for a more stable data. Expanding the company's revenue source with a fixed burden increases the profitability of the company. With increased profitability reflects a positive signal for the market to increase later the value of shares and firm value. Research (Luu et al., 2019; Setiawan and Pramika, 2019; Sharma and Anand, 2018) found that the income diversification is positively influential towards the company ROA and ROE. Then research (Aprilia and Darmawan, 2019; Hasibuan et al., 2016; Simetris and Darmawan, 2019) found that ROE positively affects the firm value.

H5: Profitability mediates the relationship between Income Diversification and Firm Value 


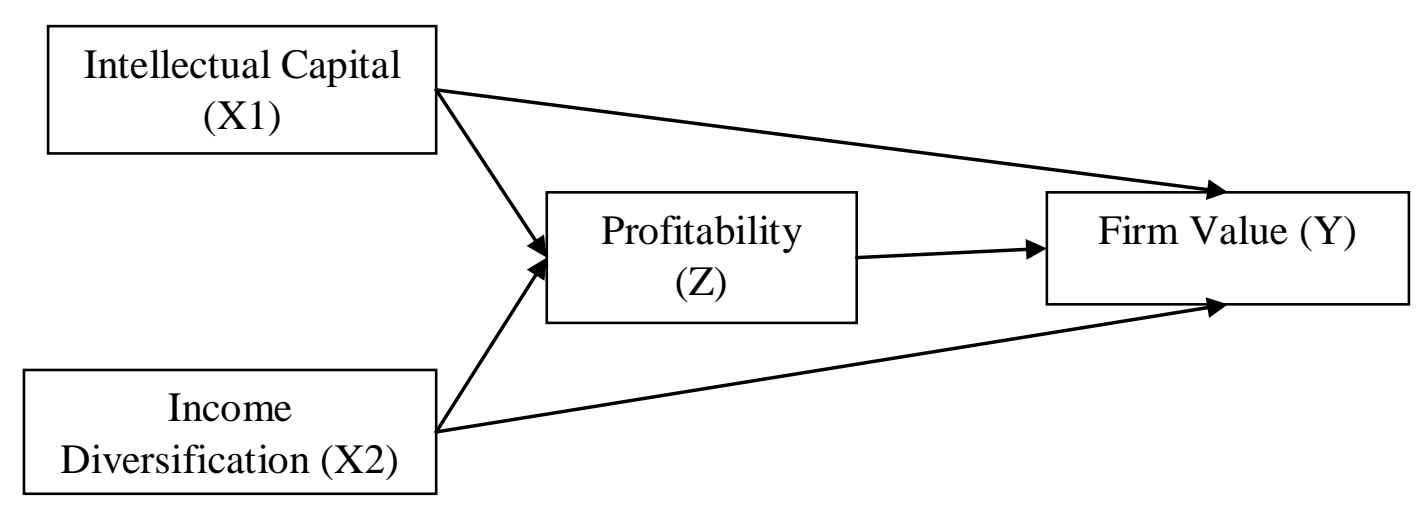

Figure 1. Research Model

\section{METHOD}

This research is a quantitative study with hypothesis testing using the Warp PLS 6.0 software. The population in this study is the entire banking of the Indonesian Stock Exchange (IDX) in the period 2013-2018, amounting to 45 banking. While sampling is based on specific criteria (purposive sampling) so it obtained 30 banking as a sample of research. Data source in the form of secondary data collected from the company's annual report through IDX official website (www.idx.co.id), company website as well as the closing stock price through the website www.duniainvestasi.com/bei/. The variables used are intellectual capital and income diversification as independent variables, firm values as dependent variables as well as profitability as an intervening variable. To measure each variable using the ratio as follows:

Table 1. Variable Operational Definitions

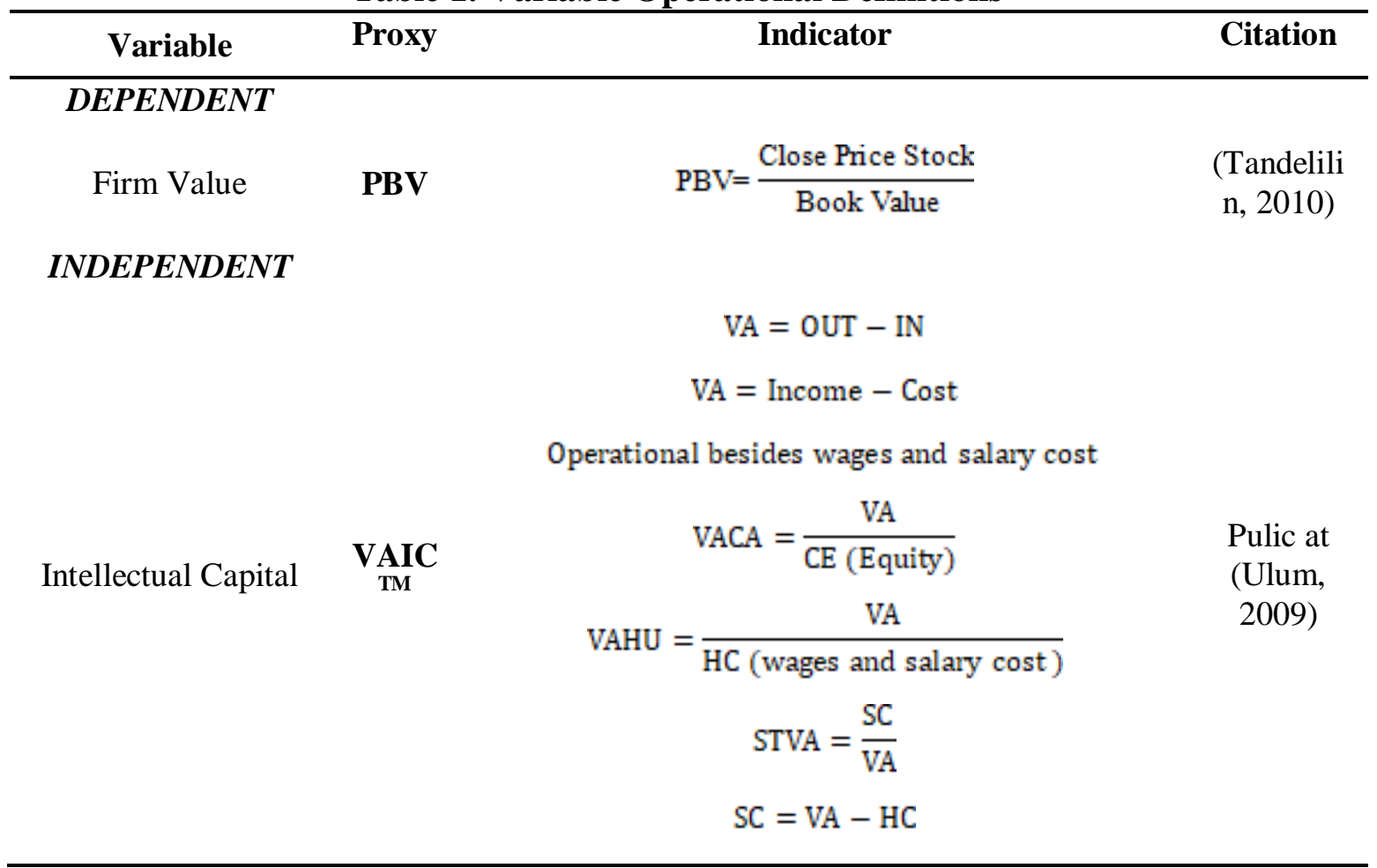




$$
\text { VAIC }^{\text {TMI }}=\text { VACA }+ \text { VAHU }+ \text { STVA }
$$

Income

Diversification

$$
\text { IDIV IDIV }=1-\frac{\text { Net Interest Income }- \text { Other Operating Income }}{\text { Total Operating Income }} \text { Levine, }
$$

2005)

\section{INTERVENING}

$\begin{array}{ccc}\text { Profitability } & \mathrm{ROA}=\frac{\mathrm{EAT}}{\text { Total Assets }} \times 100 \% & \begin{array}{c}\text { (Kasmir, } \\ 2016)\end{array} \\ \text { ROE } & \mathrm{ROE}=\frac{\text { Earning after tax }}{\text { Equity }} \times 100 \% & (\text { Kasmir, } \\ 2016)\end{array}$

Analysis of data in this research conducted consist of descriptive statistical analysis, evaluation of the Measurement Model (outer model), evaluation of structural models (Goodness of Fit/inner model) as well as test mediation with the Path analysis tool using software Warp PLS 6.0. Path analysis to test the direct or indirect relationships of the free variables and the bound variables examined.

\section{RESULT AND DISCUSSION}

Analysis of the variables in this study began with the descriptive analysis shown in Table 2.

Table 2 Statistic Descriptive

\begin{tabular}{cccccc}
\hline Variabel & Obs & Min & Max & Mean & Std. Dev \\
\hline Intellectual Capital (IC) & 180 & 0,996 & 8,903 & 2,992 & 1,135 \\
Income Diversification (ID) & 180 & 0,034 & 1,163 & 0,368 & 0,242 \\
ROA & 180 & 0,001 & 0,054 & 0,019 & 0,011 \\
ROE & 180 & 0,010 & 0,341 & 0,112 & 0,071 \\
Firm Value & 180 & 0,142 & 9,809 & 1,557 & 1,137 \\
\hline
\end{tabular}

Source: The Processed Secondary Data (2020)

Table 2 shows that in this study, there were a total of 180 observations, namely at 30 banking which was listed on the IDX with a period of 2013-2018 (6 years). The minimum intellectual capital value in DNAR in 2018 amounted to 0.996. At the same time, the maximum value is 8.903 on the SDRA 2014 with an intellectual capital average value of 2.992. Intellectual capital reflects the ability to manage existing potentials in creating Valu added. The minimum amount of the variable income diversification on MAYA 2016 is 0.034 , and the maximum value is 1.163 on the BSIM 2016 with an average value of 0.368 . Variable income diversification demonstrates the strategy that banking is doing in earning revenues, whether with a focus on interest income or a more significant source of non-interest income that reflects the diversification of income.

Profitability on the ROA proxy has a minimum value of 0.001 on BBKP year 2017 and a maximum amount of 0.054 at BBMD 2013 with an average value of 0.019 . 
Meanwhile, the profitability measured by the ROE proxy has a minimum value at BINA 2018 of 0.010 , a maximum amount of 0.341 at the BBRI in 2013 with an average ROE value of 0.112 . Profitability reflects the ability to generate profit derived from assets and equity owned. The minimum value of the firm value variable measured by PBV amounted to 0.142 in the BJBR year 2018, the maximum value of the BBRI in 2016 amounted to 9.809 with an average value of 1.557 . The value of the firm can describe the magnitude of the market valuation of the company where the stock price compared to the value of the company's stock book.

Table 3 Outer Model Result

\begin{tabular}{ccc}
\hline Variable & P-value & $\begin{array}{c}\text { Comp. Reliab. } \\
\text { and Cronbach's } \\
\text { alpha }\end{array}$ \\
\hline IC & $<0,001$ & 1,000 \\
ID & $<0,001$ & 1,000 \\
Profitability & $<0,001$ & 1,000 \\
PBV & $<0,001$ & 1,000 \\
\hline
\end{tabular}

Source: The Processed Secondary Data (2020)

Table 3 shows the evaluation of the Measurement Model (outer model), where the review is done by looking at the validity and reliability of variables and indicators. According to (Sholihin and Ratmono, 2013: 65) There is a requirement of Convergent Validity for the reflective construction, i.e. the value $p$ significance $p<0.05$. As for the results above shows the value of $\mathrm{P}$-value for each variable is worth $<0.001$ so that Convergent Validity is met and is said to be valid. The amount of composite reliability and Cronbach's alpha $>0.70$ than can be reported reliable (Sholihin and Ratmono, 2013:73). The table above shows the value of composite reliability and Cronbach's alpha for each variable amounting to 1.000 ; hence it is said to be reliable.

Table 4 Model Fit

\begin{tabular}{ccc}
\hline Indeks & P value \\
\hline Average path coefficient (APC) & 0,275 & $<0,001$ \\
Average R-squared (ARS) & 0,354 & $<0,001$ \\
AVIF & 1,170 & \\
\hline
\end{tabular}

Source: The Processed Secondary Data (2020)

The model match test is used to determine if a model is matched with data with 3 test indexes, the Average Path Coefficient (APC), Average R-squared (ARS) where it is accepted with the requirements of the $\mathrm{P}$-value of $<0.05$ and Average Variance Factor (AVIF) smaller than 5. Table 4 shows APC and ARS having a $<0.001 \mathrm{p}$-value, and an AVIF value of 1.170 was less than five so that all three indexes are accepted.

Table 5 Path Analysis Result

\begin{tabular}{ccccc}
\hline & $\boldsymbol{\beta}$ & P-value & R-Square & Results \\
\hline IC $\rightarrow$ PROFIT & 0,728 & $<0,001$ & \multirow{2}{*}{0,513} & Positive Significant \\
ID $\rightarrow$ PROFIT & $-0,128$ & 0,040 & & Negative Significant \\
IC $\rightarrow$ PBV & 0,365 & $<0,001$ & & Positive Significant \\
ID $\rightarrow$ PBV & 0,020 & 0,393 & & Not Significant \\
PROFIT $\rightarrow$ PBV & 0,289 & $<0,001$ & & Positive Significant \\
\hline
\end{tabular}




\begin{tabular}{ccccc}
\hline IC $\rightarrow \begin{array}{c}\text { PROFIT } \rightarrow \\
\text { PBV }\end{array}$ & 0,227 & $<0,001$ & & Partial Mediation \\
ID $\rightarrow \begin{array}{c}\text { PROFIT } \rightarrow \\
\text { PBV }\end{array}$ & $-0,002$ & 0,487 & & Mediation is not supported \\
\hline
\end{tabular}

Source: The Processed Secondary Data (2020)

Table 5 shows the test results of the relationship between the variables examined. The intellectual capital (IC) and profitability have a P-value value of $<0.001$ with a beta of 0.728 then statistically seen that IC positively affects profitability, so H1a is accepted. The result indicates that when the intellectual capital rises, followed by increased profitability and vice versa. These results are consistent with the research results (Alipour, 2012; Buallay, 2019; Octavio and Soesetio, 2019; Tran and Hong Vo, 2018; Wijayani, 2017). Profitability is the result of investing in intellectual capital (Amalia and Annisa, 2018). The potential of the company, both in the form of human capital and structural capital that can well manage so that creating value-added for the company can increase the company's profit, so that profitability increases. The next relationship between income diversification (ID) and statistical profitability shows the beta- 0.128 and $\mathrm{P}$-value of 0.040 , which is the income diversification negatively affect profitability, so $\mathrm{H} 1 \mathrm{~b}$ is rejected. The results supported the research (Hafidiyah and Trinugroho, 2016; Turkmen and Yigit, 2012) where income diversification in the company increases, followed by decreased profitability and vice versa. This can be due to the profit gained from non-interest business activities can not close the expenditure incurred from the declining bank interest rate (Lepetit et al., 2008). When the diversification rate increases, it leads to an increase in costs incurred and perhaps diversification may not be attributed to higher returns in each circumstance (Turkmen and Yigit, 2012). Income Diversification on top banking is reflected in high non-interest income. These revenues can be obtained from commissions and investments. In contrast, investments do not always promise high returns than the costs that have been incurred so that it may decrease the profitability of the company. The R-square IC and ID value of the profitability of $51.3 \%$ showed big or strong influence.

The influence of intellectual capital on the firm value statistically shows the 0.365 beta value with a $\mathrm{P}$-value of $<0.001$ showing positive impact, so that $\mathrm{H} 2 \mathrm{~A}$ is accepted. These results are consistent with the research (Arief and Yahya, 2014; Putra, 2012; Sudibya and Restuti, 2014) where increased intellectual capital is followed by increasing the firm value and vice versa. Management of potential well-owned or in other words of high intellectual capital can increase the value-added to be a positive signal for investors who can create value creation for the company. Meanwhile, statistically, the relationship diversification of income and firm value has a value of Pvalue 0.393 with Beta 0.020 indicating the absence of influence because the amount of significance is more than 0.05 so that $\mathrm{H} 2 \mathrm{~b}$ rejected. The results of this study supported research (Aprilia and Darmawan, 2019; Murni and Sabijono, 2018; Natalia et al., 2016; Sianipar, 2015) which can be caused because the bank is increasingly diversified at risk and Indonesian banks benefited by a high-interest margin (Hafidiyah and Trinugroho, 2016). Income Diversification requires a higher cost with the possibility of obtaining a high yield or otherwise no higher than the cost incurred to have a risk, which according to (Sudana, 2009) to increase the firm value, one of the factors that can affect that the investor generally avoids the risk. 
Statistically based on table 5 relations between profitability and the firm value shows a beta value of 0.289 with a $\mathrm{P}$-value of $<0.001$ wherein other words the profitability has a positive influence on the firm value, so the H3 is acceptable. This result is consistent with the research results (Aprilia and Darmawan, 2019; Hasibuan et al., 2016; Simetris and Darmawan, 2019). Profitability becomes one of the factors influencing in the effort to increase the firm value (Sudana, 2009). This reflects that profitability in banking can be a good signal for the market to provide a high market valuation to increase the firm value.

In this study also conducted mediation test with pathway analysis (Path Analysis) by using line $\mathrm{C}$ coefficient (in this case, the beta value). Line $\mathrm{C}$ is viewed from both relationships, namely (1) the direct link between the independent variables against the dependent (direct effect) and (2) indirect effect involving the mediation variables (Baron and Kenny, 1986). When the coefficient of line C of the second estimative result remains significant and unchanged $(\mathrm{c}=\mathrm{C}$ '), The mediation hypothesis is not supported. When the coefficient of line $C^{\prime}$ 'value drops $\left(c^{\prime}<C\right)$ but remains significant, the form of mediation is partial mediation. When the coefficient of path $\mathrm{C}$ ' The result decreases $\left(\mathrm{C}^{\prime}<\mathrm{C}\right)$ and changes to insignificant, the type of intervention is full mediation.

Based on the results in table 5 the indirect relationship between the intellectual capital of the firm value indicates the coefficient of line $\mathrm{C}$ in the direct effect more excellent than the indirect effect with a significant $\mathrm{P}$-value value of $<0.001$. Thus, the influence of intellectual capital on the firm value through profitability is partial mediation, so H4 is accepted. These results supported the study (Arief and Yahya, 2014; Hadiwijaya and Rohman, 2013; Sudibya and Restuti, 2014) where profitability can imposition the relationship between intellectual capital relations and corporate values. Besides, the indirect influence of the income diversification to the firm value in table 5 shows the amount of line coefficient $\mathrm{C}$ in the direct effect more significant than the indirect effect with the $\mathrm{P}$-value value of 0.487 remains insignificant so that mediation is not supported and H5 is rejected. This indicates that profitability is not capable of the relationship between the income diversification and Firm value. As for the amount of RSquare intellectual capital contact and income diversification to the firm value through the profitability of $19.5 \%$.

\section{CONCLUSION}

Profitability is influenced by intellectual capital and income diversification on banking in Indonesia. Intellectual capital has a positive influence on profitability, where the intellectual capital increases, followed by the rise in the profitability of banks and vice versa. Meanwhile, the income diversification negatively affects the profitability of banking. This can happen because the yield gained from the diversification process is not capable of covering the costs that have been incurred. Intellectual capital has a positive effect on the firm value, where an increase follows increased intellectual capital in firm value. Then the income diversification found no impact on the firm value in this study. High-income diversification is more at risk, and generally, investors avoid risk. The firm value is also influenced by profitability. Increased profitability is capable of being a positive signal for the market to increase firm value then. In addition to direct influence, it was found that profitability was able to mediate the relationship between intellectual capital and the firm value with partial mediation. At the same time, 
profitability has not been able to process the relationship between income diversification and corporate value in banking.

The results of this study can provide empirical evidence related to the influence of intellectual capital and income diversification to the firm value by being mediated by profitability. The limitation of this research is the result of the relationship between variables in all banking which become samples without being grouped by bank type, so it is not known in detail the influence between variables in different bank types and this research the profitability is only proxied with two proxies. Then for researchers can then group the banks in clusters so that they can be known relationship between variables on each of the different clusters, or can add variables or a measurement proxy by existing empirical theories and proofs.

\section{REFERENCES}

Aida, R. N., and Rahmawati, E. V. I. (2015). Pengaruh Modal Intelektual dan Pengungkapannya Terhadap Nilai Perusahaan: Efek Intervening Kinerja Perusahaan. Jurnal Akuntansi Dan Investasi (JAI), 16(2), 96-109. https://doi.org/10.18196/JAI-2015.0035

Alipour, M. (2012). The effect of intellectual capital on firm performance: an investigation of Iran insurance companies. Measuring Business Excelent, 16(1), 53-66. https://doi.org/10.1108/13683041211204671

Amalia, R. F., and Annisa, M. L. (2018). Analisis Hubungan Profitabilitas Dengan Modal Intelektual Perusahaan ( Studi Kasus Pada Perusahaan Pertambangan Sub Sektor Batubara di Bursa Efek Indonesia ). 3(2), 424-432.

Aprilia, A. D., and Darmawan, A. (2019). Pengaruh Diversifikasi, Leverage dan Profitabilitas Terhadap Nilai Perusahaan. Jurnal Administrasi Bisnis (JAB), 73(2), 95-104.

Arief, M. I., and Yahya, I. (2014). Pengaruh Modal Intelektual Terhadap Nilai Perusahaan dengan Kinerja Keuangan sebagai Variabel Intervening pada Perusahaan Perbankan yang Terdaftar di Bursa Efek Indonesia. Jurnal Telaah Dan Riset Akuntansi, 7(2), 142-155.

Baridwan, Z. (2011). Intermediate Accounting Edisi 8. Yogyakarta: BPFE.

Baron, R. M., and Kenny, D. A. (1986). The Moderator-Mediator Variable Distinction in Social Psychological research: Copceptual, Strategic and Statistical Considerations. Journal of Personality and Social Psychology, 51, 1173-1182.

Brigham, E. F., and Houston, J. F. (2001). Manajemen Keuangan Edisi Kedelapan Alih Bahasa. Jakarta: Erlangga.

Buallay, A. (2019). Intellectual capital and performance of Islamic and conventional banking Empirical evidence from Gulf Cooperative Council countries. Journal of Management Development, 38(7), 518-537. https://doi.org/10.1108/JMD-01-20190020

Cahya, K. D., and Riwoe, J. C. (2018). Pengaruh ROA dan ROE Terhadap Nilai Perusahaan dengan Sustainability Reporting sebagai Variabel Intervening pada Perusahaan yang Terdaftar di LQ 45. Journal of Accounting and Bussiness Studies, 3(1), 46-70.

Hadiwijaya, R. C., and Rohman, A. (2013). Pengaruh Intellectual Capital Terhadap Nilai Perusahaan dengan Kinerja Keuangan sebagai Variabel Intervening. Diponegoro Journal of Accounting, 2(3), 1-7.

Hafidiyah, M. N., and Trinugroho, I. (2016). Revenue Diversification, Performance, and 
Bank Risk: Evidence From Indonesia. Jurnal Dinamika Manajemen (JDM), 7(2), 139-148.

Hartono, J. (2012). Teori Portofolio dan Analisis Investasi. Yogyakarta: BPFE.

Hartono, J. (2013). Teori Portofolio dan Analisis Investasi. Yogyakarta: BPFE.

Hasibuan, V., Ar, M. D., and Endang, N. G. W. (2016). Pengaruh Leverage dan Profitabilitas Terhadap Nilai Perusahaan ( Studi pada Perusahaan Property dan Real Estate yang Terdaftar di Bursa Efek Indonesia Periode Tahun 2012-2015 ). Jurnal Administrasi Bisnis (JAB), 39(1), 139-147.

Kasmir. (2016). Analisis Laporan Keuangan. Jakarta: PT Raja Grafindo Persada.

Laeven, L., and Levine, R. (2005). Is There a Diversification Discount in Financial Conglomerates? NBER Working Paper, 11499, 1-58.

Lepetit, L., Nys, E., Rous, P., and Tarazi, A. (2008). Bank income structure and risk: An empirical analysis of European banks. Journal of Banking and Finance, 32(8), 1452-1467. https://doi.org/10.1016/j.jbankfin.2007.12.002

Lestari. (2017). Pengaruh Intellectual Capital \& Kepemilikan Institusional Terhadap Nilai Perusahaan. Jurnal Dinamika Ekonomi Dan Bisnis, 14(1), 17-39.

Lukmawijaya, A., and Suk, K. S. (2015). Bank Diversification Effect on Bank Performance and Risk Profile of Bank in Indonesia. DeReMa Jurnal Manajemen, 10(1), 74-84.

Luu, H. N., Nguyen, L. Q. T., Vu, Q. H., and Tuan, L. Q. (2019). Income diversification and financial performance of commercial banks in Vietnam, Do experience and ownership structure matter? Review of Behavioral Finance. https://doi.org/10.1108/RBF-05-2019-0066

Mardiyanto, H. (2008). Intisari Manajemen Keuangan. Jakarta: Grasindo.

Murni, S., and Sabijono, H. (2018). Peran Kinerja Keuangan dalam Menentuka Nilai Perusahaa. Jurnal Manajemen Bisnis Dan Inovasi, 5(2), 96-107.

Natalia, Kurniawan, M. R., and Firsty, R. R. (2016). Bank Income Diversification from Stock Market Perspective: Evidence from ASEAN +3. Indonesian Capital Market Review, 8, 32-45.

Octavio, D. Q., and Soesetio, Y. (2019). Intellectual capital and bank profitability: Evidence from conventional and Islamic bank in Indonesia. Jurnal Keuangan Dan Perbankan (JKP), 23(2), 191-205.

Purnomosidhi, B. (2006). Praktik Pengungkapan Modal Intelektual pada Perusahaan Publik di BEJ. Jurnal Riset Akuntansi Indonesia, 9(1), 1-20.

Putra, I. G. C. (2012). Pengaruh Modal Intelektual pada Nilai Perusahaan yang Go Public di Bursa Efek Indonesia. Jurnal Ilmiah Akuntansi Dan Humanika, 2(1), 122.

Salvatore, D. (2005). Ekonomi Manajerial dalam Perekonomian Global. Jakarta: Salemba Empat.

Sari, I. A., Wiratno, A., and Suyono, E. (2014). Pengaruh Strategi Diversifikasi dan Karakteristik PerusahaanTerhadap Kinerja Perusahaan. JAFFA, 02(1), 13-22.

Sartono, A. (2010). Manajemen Keuangan Teori dan Aplikasi (Edisi 4). Yogyakarta: BPFE.

Sawarjuwono, T., and Kadir, A. P. (2003). Intellectual Capital: Perlakuan, Pengukuran, dan Pelaporan (Sebuah Library Research). Jurnal Akuntansi Dan Keuangan, 5(1), 35-57.

Setiawan, R., and Pramika, M. (2019). Pengaruh Diversifikasi Pendapatan dan Bank Capital Buffer terhadap Kinerja dan Risiko Likuiditas pada Sektor Perbankan 
Syariah Indonesia. Jurnal Dinamika Ekonomi Dan Bisnis, 16(01).

Sharma, S., and Anand, A. (2018). Income diversification and bank performance: evidence from BRICS nations. International Journal of Productivity and Performance Management, 67(9), 1625-1639. https://doi.org/10.1108/IJPPM-012018-0013

Sholihin, M., and Ratmono, D. (2013). Analisis SEM-PLS dengan WarpPLS 3.0 Untuk Hubungan Non-Linier dalam Penelitian Sosial dan Bisnis. Yogyakarta: Penerbit ANDI.

Sianipar, A. S. (2015). Pengaruh Diversifikasi Pendapatan Terhadap Kinerja Bank. Jurnal Siasat Bisnis, 19(1), 27-35.

Simetris, S. A., and Darmawan, A. (2019). Pengaruh Diversifikasi, Leverage dan Profitabilitas Terhadap Nilai Perusahaan (Studi pad Perusahaan Industri Barang Konsumsi yang Terdaftar di Bursa Efek Indonesia Tahun 2013-2017). Jurnal Administrasi Bisnis (JAB), 74(1), 39-47.

Stewart, T. A. (1997). Intellectual Capital: The New Wealth of Organizations. London: Nicholas Brealey Publishing.

Subkhan, and Citraningrum, D. P. (2010). Pengaruh Intellectual Capital Terhadap Kinerja Keuangan Perusahaan Perbankan Periode 2005-2007. Jurnal Dinamika Akuntansi, 2(1), 30-36.

Sudana, I. M. (2009). Manajemen Keuangan: Teori dan Praktik. Surabaya: Airlangga University Press.

Sudibya, D. C. N. A., and Restuti, M. M. D. (2014). Pengaruh Modal Intelektual Terhadap Nilai Perusahaan dengan Kinerja Keuangan Sebagai Variabel Intervening. BENEFIT Jurnal Manajemen Dan Bisnis, 18(1), 14-29.

Sugiono. (2009). Manajemen Keuangan Untuk Praktisi. Jakarta: Grasindo.

Sunarsih, Made, N., and Mendra, N. P. Y. (2012). Pengaruh Modal Intelektual Terhadap Nilai Perusahaan dengan Kinerja Keuangan sebagai Variabel Intervening pada Perusahaan yang Terdaftar di Bursa Efek Indonesia. Simposium Nasional Akuntansi 15 (SNA 15). Banjarmasin.

Tandelilin, E. (2010). Portofolio dan Investasi Teori dan Aplikasi Edisi Pertama. Yogyakarta: Kanisius.

Tatra, W., and Wesnawati, I. A. R. (2017). Strategi Diversifikasi dan Nilai Perusahaan. Prosiding Seminar Nasional Hasil Penelitian, 175-218. Denpasar.

Tran, D. B., and Hong Vo, D. (2018). Should bankers be concerned with Intellectual capital? A study of the Thai banking sector. Journal of Intellectual Capital, 19(5), 897-914. https://doi.org/10.1108/JIC-12-2017-0185

Turkmen, S. Y., and Yigit, I. (2012). Diversification in Banking and its Effect on Banks' Performance : Evidence from Turkey. American International Journal of Contemporary Research, 2(12), 111-119.

Ulum, I. (2007). Pengaruh Intellectual Capital Terhadap Kinerja Keuangan Perusahaan Perbankan di Indonesia. Universitas Diponegoro.

Ulum, I. (2009). Intellectual Capital: Konsep dan Kajian Empiris. Yogyakarta: Graha Ilmu.

Werastuti, D. N. S. (2014). Model Moderasi dalam Hubungan antara Intellectual Capital Discloure, Nilai Perusahaan, dan Financial Performance. Jurnal Keuangan Dan Perbankan, 18(1), 14-28.

Widiasari, F. W., and Pangestuti, I. R. D. (2015). Pengaruh Struktur Pasar, Kompetisi,Diversifikasi,Kapitalisasi, Risiko Kredit, dan Size Terhadap 
Profitabilitas Bank. Diponegoro Journal of Management, 4(2), 1-12. Retrieved from http://ejournal-s1.undip.ac.id/index.php/dbr

Wijayani, D. R. (2017). Pengaruh Intellectual Capital Terhadap Kinerja Keuangan Perusahaan Publik di Indonesia. Jurnal Riset Akuntansi Dan Bisnis Airlangga (JRABA), 2(1), 97-116. 